\title{
Migracija, mobilnost, rod
}

DOI: $10.11567 /$ met.29.1.4

\section{Ružica Čičak-Chand}

Zagreb

Knjiga Migration, Mobilität, Geschlecht urednica Meike Penkwitt i Antonie Ingelfinger (Budrich UniPress Ltd., Leverkusen - Opladen, 2011, 380 str.) predstavlja tematski raznorodnu raspravu o aspektima migracija, prije svega iz migrantske perspektive, $u$ čemu je osobita vrijednost ove studije, uključujući postkolonijalne teorije i njihovu primjenu kroz slike i teme obrađene u knjizi. Propituje se, kako i naslov kaže, bliska povezanost pojma »migracija « s pojmovima »mobilnost « $\mathrm{i}$ »rod «, jer migracija već sama po sebi uključuje kretanje, mobilnost. Ipak, između migracije i mobilnosti postoji kompleksna veza, kako uvodno napominje urednica Ingelfinger. Naime mobilnost migranata nije bez ograničenja. Iz odnosa prema izbjeglicama, posebice iz sjevernoafričkih zemalja, jasno je da se zajednica europskih država, za čije je građane pojam mobilnosti središnja, poglavito pozitivna kategorija njihove radne i životne zbilje, brani od mobilnosti stanovnika izvan europskoga kontinenta kako bi zaštitila privilegije vlastitih ljudi. Da je migracija i rodno determinirani proces, upućuju analize biografija migranata/ migrantica i njihovih specifičnih situacija u zemljama imigracije. No kako pokazuje složena interakcija između društva primitka i migranata, kategorija »roda «, ističe Ingelfinger, obuhvaća i druge diferencirajuće kategorije poput rase/etničnosti, klase i seksualnosti, koje upravo u kontekstu migracija postaju značajne.

Trijada pojmova migracija, mobilnost, rod otvara tako široko interdisciplinarno istraživačko područje u kojem značajni udio imaju sociologija migracija, interkulturna pedagogija, rodne studije, postkolonijalne studije, etničke studije, ali i politika, pravo i ekonomija. Humanističke pak znanosti okrenute su više prema kulturnim ostvarenjima migranata u zemljama primitka te njihovu utjecaju na kulture društava tih zemalja.

Istraživanje migracija dugo je polazilo od pretpostavke da samo muškarci migriraju iz ekonomskih, političkih ili vjerskih razloga. U međuvremenu je prihvaćena činjenica da gotovo u jednakom broju migriraju i žene, i to ne samo kao pratilje svojih muževa ili roditelja već i dijelom iz istih razloga kao i svoji muški sunarodnjaci, pa se danas sve češće govori o »feminizaciji migracija«. Ta se spoznaja odražava i na sama istraživanja jer se i u zemljama 
primitka bitno razlikuju iskustva kroz koja prolaze žene odnosno muškarci, ovisno o uvjetima rada, predrasudama te različitosti kulturnih predodžbi kako zemalja porijekla tako i zemalja useljenja.

Osim šireg uvoda urednice Antonie Ingelfinger »Migration - Mobilität Geschlecht. Eine Einleitung «, na koji se djelomice referira i ovaj osvrt, knjiga sadržava petnaest priloga, od toga dva filmska, Forum te veći broj prikaza i recenzija. U osvrtu je zbog tako velikog broja tekstova raznovrsne tematike i pristupa moguće šire se osvrnuti samo na neke, prije svega na prva dva ključna teksta koja se tiču postkolonijalnih teorija, osobito promišljanja Gayatri Chakravorty Spivak.

Četiri članka napisale su same migrantice, Njemice migrantskog porijekla. Nekoliko tekstova bavi se migrantskim situacijama u Njemačkoj, Švicarskoj i Francuskoj; jedan tekst istražuje obilježja transnacionalnih spona sa zemljom porijekla. Svi članci osim jednoga radovi su žena znanstvenica, sveučilišnih profesorica, njih devet sa Sveučilišta u Freiburgu.

Prema Ingelfinger, jedan od problema $u$ odnosima između migranata $i$ društva primitka jest što se migranti često percipiraju statično, kroza zamišljene kulturne razlike, etnije, bilo u pozitivnom, bilo negativnom smislu. Omeđenje »stranaca « kulturnim ili etničkim razlikama omogućuje jasno razgraničenje od njih, i u tom kontekstu dolazi do kategoriziranja migranata, odvajanja od lokalne većine i umanjivanja njihove vrijednosti. Migranti se, također, nerijetko doživljavaju kao pasivan problem, a ne kao aktivni ljudi koji znaju i žele rješavati probleme; premalo se pravi razlika između migrantskih skupina. U vezi s rasističkim i etničkim stigmatiziranjem, $\mathrm{u}$ cilju isticanja razlika spram stranaca, primjerice između »emancipirane Njemice« $\mathrm{i}$ »podčinjene muslimanke«, može se prepoznati novi interesantni aspekt odnosa prema strancima/strankinjama. Ovdje je riječ o mitu koji s jedne strane muslimanske migrantice obilježava kao "podrazvijene« i otežava im pristup tržištu rada, a s druge pomaže naoko emancipiranoj Njemici odvraćajući joj pozornost od činjenice da unatoč svim službenim uvjeravanjima stvarna ravnopravnost između muškaraca i žena u Njemačkoj tek predstoji.

Problem je i u tome što uglavnom obrazovani bijelci i bjelkinje, pripadnici srednjeg sloja, znanstvenici i političari posjeduju moć definiranja pojmova i ljudi, dok se o perspektivama $\mathrm{i}$ istraživanjima migranata i migrantica malo zna, i mari. U međuvremenu, ipak, raste broj istraživanja koje provode migranti i koja upozoravaju na propuste u vladajućem diskursu te se kritički odnose prema rezultatima studija mainstreama, upozoravajući na 
postuliranu objektivnost istraživanja kao rasističku i premalo refleksivnu, o čemu je riječ i u ovoj knjizi.

Svakako, početni impuls knjizi daju, kako je već istaknuto, prva dva priloga koja se bave postkolonijalnom teorijom, posebice teorijskim promišljanjima književne kritičarke, filozofkinje i aktivistkinje indijskog porijekla Gayatri Chakravorty Spivak. Tako anglistica Miriam Nandi (Sveučilište Freiburg) u radu »Postkoloniale (Selbst-)kritik: Geschlecht und Migration bei Gayatri Chakravaty Spivak« analizira tekstove koji se tiču postkolonijalnih rasprava, a koje Gayatri Spivak tumači kao postkolonijalnu (samo)kritiku. Autorica ovdje dotiče pitanje isključivanja unutar same postkolonijalne nacije odnosno migrantske zajednice, ali bez posezanja za kolonijalnim, rasističkim klišejima. Pita: »Je li moguće teoretizirati o ugnjetavanju žena unutar migrantskih zajednica, s njima se solidarizirati, bez obnavljanja rasističkoga klišeja o muslimanima koji su nasilni prema ženama i podcjenjuju ih?«(str. 36). U tom kontekstu valja ponajprije razmotriti ključne pojmove postkolonijalizma, smatra Nandi, a potom se osvrnuti na kritiku Chakravorty Spivak, koja postkolonijalnome mainstreamu suprotstavlja klasno senzibilizirajuću i rodno senzibilizirajuću znanost kulture.

Tim slijedom u podnaslovu članka »Postkoloniale Theorie« autorica uvodi osnovne pojmove postkolonijalnosti, dajući značajan prostor analizi i kritici orijentalnog diskursa Edwarda Saida. Postkolonijalne studije nisu samo vremenski post već su i politički mišljene, podcrtava Nandi, analizirajući s jedne strane procese koji se odvijaju nakon i tijekom kolonizacije, a s druge strane okreću se obespravljenima, nevidljivima i »bezglasnima«. Postkolonijalizam nije prema tome samo novi oblik pisanja povijesti već je ujedno i pokušaj promjene perspektive, probijanje europocentričnog promišljanja, proširenje globalne geografske karte na Jug i Istok.

Nandi se osvrće i na postkolonijalni pojam hibriditeta Homi Bhabe te koncept »Writing Back« australskih teoretičara Ashcroft, Griffith i Tiffen govoreći o miješanju, hibridiziranju lokalnih i kolonijalnih elemenata.

Koncepti uključivanja odnosno isključivanja mogli bi upravo u današnjem vremenu, smatra autorica, dati odgovor na učestale rasprave o stupnju (ne) integracije migranata. Umjesto podjele migranata na »dobre ili loše subjekte«, na one koji su se »dobro« ili »loše« integrirali, treba promijeniti kut gledanja; naime usvajanje (njemačkog) jezika i kulture valja moći sagledati i iz migrantske perspektive.

Autorica se potom vraća na kritiku postkolonijalnih paradigmi Gayatri Chakravorty Spivak, na činjenicu da se postkolonijalnom subjektu per se 
pripisuje status podčinjenosti. Prema Chakravorty Spivak, žrtve kolonijalnog ugnjetavanja u poziciji moći lako same postaju počinitelji. Stoga njezin istraživački program, ističe Nandi, treba ponajprije razumjeti kao traženje onoga što (još) nedostaje: što nedostaje u postkolonijalnoj raspravi (fokus na izrabljivanje radne snage, posebice ženske, na Istoku i Jugu), zapadnjačkom feminizmu (razumijevanje za rasu i klasu) i marksističkoj teoriji (teorija o razumijevanju spolnosti). Chakravorty Spivak često govori o potlačenoj ženi, radnici s Juga. Za Chakravorty Spivak su postkolonijalne feministkinje na određeni način sukrivci, već i zbog činjenice da u svojoj svakodnevici sudjeluju u ekonomskom i ekološkom iskorištavanju Trećeg svijeta. U svojemu glavnom djelu Critique of Postcolonial Reason Chakravorty Spivak, između ostaloga, vrlo konkretno piše o velikim tekstilnim koncernima Zapada koji zapošljavaju radnice iz zemalja Trećeg svijeta pod nedostojnim uvjetima, za smiješno niske nadnice. Ugodan život postindustrijskih nacija temelji se, prema Chakravorty Spivak, ne malim dijelom na eksploataciji radnica s Juga i onih u istočnoeuropskim zemljama. Stoga je za Chakravorty Spivak zadaća postkolonijalnih intelektualaca prepoznati to suučesništvo i radikalno o njemu progovoriti. Pored sve kritike Chakarvorty Spivak ne odbacuje postkolonijalnu teoriju, naprotiv, nadopunjuje ju usredotočujući se na položaj ugnjetavanih žena (s Juga), koje ni u postkolonijalnoj teoriji ni u rodnim studijama, pa niti u marksističkome mainstreamu ne nalaze pravo na artikulaciju svojeg položaja.

U dijelu teksta »Über-setzungen aus anderen Welten: Geschlecht und Migration « Nandi govori o konceptu prevođenja koji je, osobito u posljednjem desetljeću, pojačano prisutan u postkolonijalnoj teoriji, djelomice i kroz poticaj Chakravorty Spivak. Prevođenje kod Chakravorty Spivak nije tek jezični fenomen već uvijek i stanoviti oblik prevođenja kulture, čin koji zahtijeva puno intimnosti s kulturom iz koje tekst potječe. Stoga valja razmisliti ne bi li i migracije trebalo shvatiti kao određeni proces "pre-vođenja«. Konačno, migranti i migrantice uvijek su i samo pojedinci koji moraju moći "pre-vesti« sebe u novo društvo i njegovu kulturu. Ta je ideja, mišljenja je Nandi, manje europocentrična i manje rasistička od sveprisutnoga koncepta integracije migranata.

Ukratko, samo Spivakino stvaranje oblik je "pre-vođenja«, kretanja, proces migriranja. Chakravorty Spivak pomiče feminizam prema Jugu i Istoku, prevodi marksizam u jedan feminističkiji, kulturološki senzitivniji govor. Ona nema jednostavne odgovore na pitanje što činiti da oni koji su meta zapadnog rasizma ne posegnu za istim oblicima eksploatacije u vlastitim 
zajednicama. Pa iako bez konkretnih odgovora, njezino je upozoravanje na teorijske manjkavosti i nedorečenosti unutar postkolonijalizma i rodnih studija obogatilo obje discipline. Iskorištavanje radnica na Jugu te nerijetko nesiguran i neravnopravan položaj žena unutar migrantskih zajednica, nisu se doduše promijenili, ali je njezina kritika ipak pridonijela da ta tema postupno uđe $\mathrm{u}$ fokus akademskih interesa i rasprava. Možda je Spivakinu teoriju moguće prevesti i u određeni politički idiom, zaključuje Nandi.

Mariam Popal, islamologinja i iranistica na sveučilištu Freiburg, porijeklom iz Afganistana, u tekstu »'Gender'. Mythen - Masken - Subjektpositionen - und beyond « kritički se dotiče značenja pojmova migracija, mobilnost i rod. Referirajući se na razmišljanja Chakravorty Spivak o značenju prevođenja na drugi jezik te kroz vlastito iskustvo »obojene žene« u njemačkoj akademskoj svakodnevici, Popal slijedi pojmovima zakrivenu povijest nastanka njihova značenja upozoravajući kako su pojmovi »produkt« do danas neupitnog statusa bjelačke dominacije koja priječi drugačije mogućnosti govora i prikriva drugačije oblike života.

Popal skreće pozornost na činjenicu da se prevođenje ne shvaća više kao doslovno prevođenje riječi ili transkodiranje jezika ili idioma, a još manje znači komunikaciju koja bi pretpostavljala ravnopravnost položaja jezikâ. Najkasnije od lingvističkog obrata u drugoj polovini 20. stoljeća jezici se počinju razumijevati kao proces konstrukcije značenja. Postkolonijalni tekstovi naglašavaju pritom povijesne i političke kontekste tih značenjskih konstrukcija unutar pojedinih struktura moći.

Govoreći o različitim maskama, Popal uvodi u svoj rad esej »No Masks« (2005) Grade Kilomba, profesorice na sveučilištu u Berlinu, koja opisuje dvojako značenje dekonstrukcijskog pojma »maske«: s jedne strane govori o faktičnoj uporabi maski za mučenje robova u vrijeme kolonijalne trgovine robljem, a s druge o njezinu simboličnom značenju, u funkciji isključivanja i marginaliziranja drugih (njezin su primjer njemačke sveučilišne institucije i bijeli znanstvenici), čiji govor u javnosti treba onemogućiti, dok pripadnicima bijele rase, bjelačkoj znanosti, valja osigurati središnju poziciju. Otuda se i obrazovni sustav može iščitavati kao proizvođenje »maski« koje diferenciraju čije su riječi vrijedne da se čuju i čitaju. Prema Kilombi, riječ je o kartografiji u kojoj rasa određuje položaj; unutar nje bijelost predstavlja dominaciju i mobilnost, a obojenost označuje rubnost, potisnuće. Označivanje drugosti bojom kože ili religijom istodobno znači (us)postavljanje granice. Granica čuva bijeloga subjekta unutra, a drugog, jer nije "pravi«, ostavlja vani pa se tako u tijesnom prostoru, unutar sustava koordinata bijelosti, liberaliz- 
ma, mobilnosti i govora, mogu očuvati obilježja drugog. Stoga je to važnije bijelost otvoreno imenovati. Migracija i mobilnost ne samo da često okrutnu zbilju bijega čine nevidljivom, one jednako maskiraju i prešućuju pozicije Sjevera, prave ih nevinima jer, globalno gledajući, većina ljudi ne može migrirati (pitanje je bi li ljudi uopće migrirali da nisu primorani).

U Europi/Americi rat u Afganistanu opravdava se, ističe Popal, rodnom argumentacijom; rodnost je poslužila misionarskoj priči o oslobađanju potlačenih Afganistanki od njihovih muških sunarodnjaka, predstavljajući američki feminizam kao feminizam par excellence. Ženska organizacija RAWA (Revolutionary Association of the Women of Afghanistan), koja je i pod vlašću talibana, osobito u području obrazovanja, ostala aktivna, u međuvremenu traži povlačenje američkih snaga, upozoravajući na katastrofalne životne uvjete sveg stanovništva u Afganistanu, ne samo »žena«. Tako je rodna retorika, s kojom je rat u Afganistanu iznova počeo, podjelom na dobre ali bespomoćne žene te na zle, bradate muškarce, neprijatelje žena, grubo nametnuta slika odnosa među spolovima kojom se opravdava ratovanje sa svim njegovim strašnim i trajnim posljedicama.

Prilozi »Identität und Migration im Zeitgenössichen Tanz« (Monica Alarcon) $i$ »Black Barbie \& Co. Migrations- und Rassismuserfahrungen in Songtexten französischer Rapperinnen « (Eva Kimminich) istražuju utjecaje migrantskih odnosno interkulturnih iskustava na polju glazbe i plesa.

Monica Alarcon istražuje kako procesi globalizacije utječu na lokalne sredine, kako raste broj onih koji istovremeno žive u više kultura te kako suvremene plesne grupe odražavaju te nove globalne stilove, pa i kroz svoje internacionalne sastave. Prema mišljenju Alarcon, ples promiče uspješni model izgradnje transkulturnih identiteta.

Romanistica Eva Kimminich piše o ženskoj rap-kulturi u Francuskoj, prezentirajući načine na koje su reperice stvorile vlastite autentične slike na inače pretežito muškoj sceni, pri čemu njihove osobne životne priče, pretočene $u$ tekstove, igraju važnu ulogu. Na primjerima triju reperica istražuje na koji se način te umjetnice koriste kulturološkom tehnikom rapa za predstavljanje svojih identiteta kao žena migrantskog porijekla, odnosno reperica u jednoj uglavnom muškoj domeni.

Književna znanstvenica Weertje Willms u prilogu »Männlichkeitskonstrukte in Texten türkisch-deutscher Väter und Söhne: Autorinnen und Autoren« bavi se konstruktom muškosti u tursko-njemačkoj književnosti na primjerima četiriju literarno različitih tekstova. Razlike proizlaze ponajprije iz pripadnosti protagonista različitim generacijama i društvenim slojevima. U dva teksta (Fethi Savasc, »Bei laufenden Maschinen«, i Emine Sevgi Őz- 
damar, »Schwarzauge in Deutschland «) iz perspektive očeva, nastala 80-ih, opisane su sudbine turskih "gastarbajtera $u$ Njemačkoj. I dok njihov nacionalni identitet kao Turaka ostaje neupitan, njihov rodni identitet $u$ razdoblju »gastarbajtovanja«, prema autorici, bitno je urušen. Doduše turski gastarbajteri ni u Turskoj ne pripadaju krugu predstavnika dominantne »muškosti «, no u Njemačkoj su sasvim marginalizirani, isključeni iz »muške « kulture kao takve, jer su socioekonomski svedeni na mentalno nedoraslu, obespravljenu radnu snagu, ističe Willms. No u opisu generacije sinova model muškosti razlikuje se ovisno o pripadajućemu društvenom sloju. Mladi muškarci nižega društvenog položaja (Feridun Zaimoglu, »Kanak Sprak«, 1995) izgrađuju vlastiti, pozitivno obilježeni pojam muškosti, ograđujući se od svojih očeva, ali i od svojih vršnjaka Nijemaca, koje jednako omalovažavaju. Taj koncept stvoren prema strogim i arhaičnim propisima odvaja njihove članove i od ostalih grupa. Nasuprot tome, među obrazovanim slojem (Yade Kara, »Selam Berlin«, 2003), unutar širokog spektra globalnih koncepata formiraju se, prema Willms, modeli muškosti koji su i transnacionalni i transrodni te su stoga društveno sposobni da se održe i okrenuti su prema budućnosti.

Suprotno od germanistice Willms, amerikanistica Selma Erdogdu-Vollmerich u "'Aus dem Bauch heraus?' Reading Sevgi Özdamar's Das Leben ist eine Karawanserei (1992) and Edwidge Danticat's Breath, Eyes, Memory (1994) « istražuje konstrukte identiteta migrantica u književnosti, manje obilježene njihovim migrantskim iskustvom, a u mnogo većoj mjeri javnim i akademskim odnosom spram te literature i njihovih autorica. Izabire primjer uspješne njemačko-turske spisateljice Emine Sevgi Özdamar, koja je za Das Leben ist eine Karawanserai, hat zwei Turen, aus einer kam ich rein, aus der anderen ging ich raus dobila nagradu Ingeborg-Bachman, te jednako popularne haitsko-američke spisateljice Edwige Danticat, čiji je roman Breath, Eyes, Memory izabran za književni klub Oprah Winfrey.

Erdogdu-Vollmerich bavi se ovdje pitanjem značenja mjesta roda i migracije u kritičkoj recepciji dvaju spomenutih literarnih tekstova. Naime dok književna kritika »prepoznaje« Ôzdamar kao tursku autoricu koja jednim egzotičnim tekstom osvaja visoku njemačku nagradu, dotle je roman spisateljice Danticat, u čijem je središtu odnos majke i kćeri, u književnom klubu Oprah prihvaćen kao kulturno »transcendirajući«, »univerzalan«, čime se zanemarila potencijalna »drugačijost« čitanja teksta, ali i njegove autorice. Erdogdu-Vollmerich stoga zaključuje da je recepcija obaju romana pretežito usredotočena na sadržaj(e), dok su estetski aspekti romana ostali, nažalost, izvan interesa i književne kritike i čitalačke publike. 
Sljedeća dva priloga propituju feministički angažman unutar kršćanske odnosno muslimanske teologije koji potječe od migrantica i njihovih specifičnih iskustava.

Tekst katoličke teologinje Margit Eckholt, profesorice na sveučilištu Osnabrück, »Beyond any boder - Feministische Theologie der Befreiung in Zeiten der Migration« prezentira teologiju »na granici«, koju su razvile latinskoameričke teologinje u SAD-u na temelju radova feminističke teologije oslobođenja. Ovdje »granica«, prema Eckholt, postaje novi locus theologicus, kreativno mjesto na kojem se obilježja vremena - globalizacija, migracija, siromaštvo, kulturni i vjerski pluralizam - susreću i povezuju. Migrante i migrantice iz latinskoameričkih zemalja Eckholt doživljava kao kulturno pluralnu zajednicu koja mijenja američko društvo premda je još uvijek premalo prepoznata. Da bi naglasila važnost promjena, Eckholt uvodi u svoj rad istaknutu latinskoameričku teologinju Mariu Pilar Aquino sa sveučilišta San Diego, za koju je feministička interkulturna teologija etičko-politička alternativa naspram prevladavajuće opće društvene nepravde te osobito subordinacije žena. »Bivanje između « postalo je za Aquino, prema Eckholt, novom metaforom određenja mjesta, tumačenja života s obje strane granice te $\mathrm{u}$ konačnici razvijanje teologije »beyond any border«. Dok je feministička kritika kršćanstva najkasnije od sredine 20. stoljeća dovela do kritičkog preispitivanja Biblije i njene androcentrične i patrijarhalne slike svijeta te stvaranja feminističke teologije, dotle se pravo da Kuran i druge islamske tekstove tumače isključivo muslimanski teolozi znatno duže zadržalo. Naime tek 90-ih prošloga stoljeća pojavljuje se veći broj aktivistkinja koje, uz pomoć različitih hermeneutičkih, epistemoloških, historijskokritičkih metoda te alternativne interpretacije Kurana i drugih tekstova, kritički propituju dotadašnja učenja, patrijarhalne pristupe čitanju i tumačenju. Taj se trend obilježava kao »islamski feminizam «, a migranticama se pritom pripisuje vodeća uloga. Islamska znanstvenica Roswitha Badry u tekstu »Der friedvolle 'gender-dschihad' muslimischer Aktivistinnen gegen patriarchalische Lesearten des Korans - 'Islamischer Feminismus' in der Diaspora als Wegbereiter fur ein globales Phänomen? « prezentira akademske napise muslimanskih migrantica koji idu u smjeru dekonstrukcije šerijata i antipatrijarhalnog čitanja Kurana upozoravajući istodobno na mogućnosti, ali i manjkavosti pokreta »feminističke teologije«, koji je još uvijek u procesu formiranja u odnosu na već etabliranu feminističku teologiju unutar kršćanstva.

Slijede prilozi koji se temelje na empirijskim istraživanjima situacija migranata ili njihove dijaspore u Njemačkoj, Švicarskoj i Francuskoj te na Kapverdskim otocima. 
Članak sociologinje Wiebke Waburg i pedagoginje Verene Schurt (obje sa Sveučilišta Augsburg) »Geschlecht, Ethnizität, Bildungsungleichheit: Ergebnisse und Potenziale interkultureller Geschlechterforschung in der Schule« bavi se nejednakostima u njemačkome obrazovnom sustavu koncentrirajući se na razlikovne kategorije roda i etničnosti i njihovu međusobnu isprepletenost. Uvodno autorice upozoravaju na raširenu prisutnost rodnih predodžbi o migranticama i migrantima u njemačkom društvu te na stalnu reprodukciju stereotipâ u medijima u skladu s predodžbama o tradicionalnim odnosima među spolovima u migrantskim obiteljima. Pitanje je kako »osloboditi« škole od tradicionalnog razumijevanja roda i rodnih odnosa, koji se, nerijetko i u znanosti, primarno vezuju uz etničnost/kulturu. S obzirom na oskudna empirijska istraživanja nije primjerice moguće dobiti jedinstveni odgovor jesu li djevojčice iz migrantskih obitelji u odnosu na dječake u prednosti ili na gubitku. Posebice ako se razlike ispituju prema etničkim skupinama, međusobni utjecaj roda i etničnosti može se pokazati izrazito proturječnim. Ipak, općenito, uzimajući u obzir kategorije spola i etničnosti, učenice iz migrantskih obitelji u prosjeku postižu bolje rezultate u školama u odnosu na mlade migrante. No na tržištu rada, u profesionalnom životu, unatoč formalnim kvalifikacijama, mlade žene migrantskog porijekla (slično kao i pripadnice većinske populacije) u pravilu imaju slabije šanse za zapošljavanje.

Usporedba uspjeha alohtonih i autohtonih učenika u školama (bez obzira na spol), na općoj razini, pokazuje da mladi migranti češće napuštaju školu bez svjedodžbe završenoga općeg obrazovanja/škole (Hauptschule); sukladno tome, mladi stranog porijekla značajno su podzastupljeni u stručnim odnosno na višim ili visokim školama. No mora se upozoriti na činjenicu, ističu autorice, da učenici migrantskog porijekla nisu nikakva homogena skupina. Zaostajanje u školovanju zamjećuje se najčešće kod učenika turskoga odnosno talijanskog porijekla, dok primjerice mladi iz Poljske i zemalja bivšega Sovjetskog Saveza u odnosu na većinu zauzimaju srednju poziciju. Heterogenost rezultata posljedica je brojnih čimbenika, poput socijalnog porijekla, migrantskog statusa, duljine boravka, motivacije prilikom migriranja, roditeljskog stava i aspiracija prema edukaciji djece, ali i utjecaja određenih efekata kao primjerice prijetnji od stereotipnih predodžbi, kojima su posebno izložene neke skupine stranaca.

Autorice naglašavaju važnost interkulturnog istraživanja roda u okviru suvremenog istraživanja škola. Naime kulturni sukob u njemačkim školama sve se češće inscenira kao sukob među spolovima. Migrantice se pritom prikazuju kao bespomoćne žrtve, a migranti kao potencijalni nasilnici. Ta- 
kve i slične konstrukcije, prije svega relevantne kad je riječ o tursko-islamskim migrantima/migranticama, trebale bi uputiti na tobožnje arhaične odnose među spolovima unutar migrantskih obitelji nasuprot emancipiranim predodžbama rodnih odnosa njemačkoga društva odnosno zapadnoeuropskih društava uopće.

Na situaciju u Njemačkoj odnosi se i prilog socijalne pedagoginje Debore Niermann »'Ich muss die Familie ziehen, ich als Mann': Geschlechter- und Familienbeziehungen von Männern mit osteuropäischen Migrationshintergrund in Deutschland «, koji počinje autoričinim osvrtom na aktualno stanje $\mathrm{u}$ domeni istraživanja rodnih i obiteljskih odnosa muškaraca iz istočnoeuropskih zemalja, konstatirajući opću manjkavost istraživanja migracija kao obiteljskog projekta. U prikazu rezultata svoje empirijske studije Männer Leben - Familie und Migration im Lebenslauf von Männern (2008/2009) Niermann upozorava na prevladavajuću konstrukciju muškosti, »muškarac kao hranitelj obitelji«, među ispitanicima. Takav je stav, pokazalo je istraživanje, neovisan o društvenom položaju ispitanikâ migranata. U usporedbi s recentnim društvenim promjenama rodnih odnosa u Rusiji, autorica podcrtava da pri tom tradicionalnom tumačenju muškosti nije riječ o promjeni do koje je došlo (samo) zbog emigriranja u Njemačku. Naprotiv, Niermann naglašava istovremenost pojave repatrijarhalizacije kod muškaraca u postsovjetskim državama te kod migranata istočnoeuropskog porijekla u Njemačkoj. No u tom kontekstu, napominje, zasada ne postoje istraživanja koja bi govorila o konceptima obiteljskih i rodnih odnosa iz ženske perspektive i njihove moguće mijene s obzirom na proces retradicionalizacije.

Na novosti u zakonu u vezi sa statusom stranaca i azilanata u Švicarskoj kritički se osvrće anglistica Jana Häberlein $\mathrm{u}$ »Von Ehehäfen und Ausschaffungsflugen: (Persistente) Geschlechternormen und normalisierende Regulationen im neuen Schweizer Auslandergesetz« (2007/2008) upozoravajući na glavne ciljeve revizije zakona koji s jedne strane donose pojedinačna poboljšanja u pravnom položaju stranaca, dok je s druge cilj novih zakona pospješiti integraciju migranata, ograničiti useljavanje iz trećih zemalja te suzbiti moguću zloupotrebu. Autorica posebnu pozornost posvećuje novoj regulaciji tzv. »prividnih brakova « i mogućnosti nepriznavanja ex lege očinstva. Pritom je problematična činjenica što su kriteriji koji bi upućivali na moguće zloupotrebe krajnje nedefinirani (navodi primjer Ureda za migracije švicarskoga kantona Thurgau koji je sastavio katalog s osamdeset pitanja u svrhu »razotkrivanja « pravih namjera bračnih partnera). Autorica potom skreće pozornost na pitanje zakonskog reguliranja nepriznavanja očinstva, koje ima političku svrhu: odbijanje dozvole boravka na osnovi očinstva i 
odnosa s djetetom, što uključuje izgon iz zemlje. U konačnici, novi zakon u pogledu sklapanja binacionalnih brakova odnosno nepriznavanja očinstva migrantima iz trećih zemalja, zorno oslikava, prema Häberlein, jedno zatvoreno društvo koje ne prihvaća kulturni pluralizam kao činjenicu i živuću praksu; naprotiv, pluralnost doživljava ugrožavajućom i stranom. Na primjerima službene prakse Häberlein u reviziji zakona o strancima iščitava seksističke i rasističke propise te zbog posljedica koje oni imaju za pojedine skupine stranaca, vidi u njima dodatni način kontrole imigracije i stanovništva uopće.

Sociolog Ĕric Fassin u prilogu »Das Geschlecht der Immigration in Frankreich « upozorava na promjene $\mathrm{u}$ francuskoj useljeničkoj politici, koja je u međuvremenu, prema autoru, postala stvar roda, i to kako u pogledu roda tako i seksualnosti. U tekstu autor slijedi razvoj novoga političkog diskursa u zemlji, nametnutog od 2000. godine kroz javne rasprave o prostituciji, poligamiji i prisilnim brakovima, fokusirajući se na migrante/migrantice i njihove potomke. Pa ipak, upozorava, politička definicija useljenica kao žrtava nije im zajamčila očekivana prava, kako je pokazala praksa, već je, naprotiv, opravdala politike usmjerene protiv useljavanja, koje osim muškaraca pogađaju i žene. Rasizam je pritom sastavni dio te političke logike koja se nametnula u Francuskoj i Europi: useljavanje žena u središtu je politike čiji je moto suzbijanje takozvane »trpljene« imigracije u ime obrane načela integracije. Politika nacionalnog identiteta zasnovana na retorici »spolne demokracije«, pri čemu biti Francuz/Francuskinja, navodno, podrazumijeva slobodu i jednakost među spolovima, sukobila se $\mathrm{s}$ iskustvenom zbiljom brojnih afričkih migranata i migrantica, muslimana i muslimanki. Političke strategije protiv neželjene imigracije, protumačene kao obrana demokratskih vrijednosti, negativno se odražavaju na privatni život migranata i migrantica, između ostalog i time što se binacionalni brakovi, kao i migranti koji podnose molbu za useljenje na osnovi zakona o spajanju obitelji, a priori nalaze pod sumnjom. Njihovo pravo na privatni obiteljski život u ime spolne demokracije ozbiljno je narušeno. Fassinova zapažanja govore ustvari o tome kako se politika nacionalnog identiteta u Francuskoj danas slama preko tijela strankinja, a u slučaju binacionalnih parova i preko Francuskinja.

Zadnji prilog govori o transnacionalnim sponama između migranata i njihovih obitelji, odnosno djece i rođaka koji su ostali u zemlji porijekla. Etnologinja Heike Drotbohm u »Die Grenzen geteilter Sorge. Arrangements zwischen Geschlechtern, Generationen und Rechtsdeutungen in transnationalen kapverdischen Familien « tematizira na primjeru transatlantičke migracije iz zapadnoafričke otočne države Kap Verde obiteljske odnose koji su 
se zbog feminizacije migracija od 70-ih godina 20. stoljeća značajno promijenili; sada migrantice organiziraju skrb i brigu za djecu, starije ili bolesne članove obitelji. Drotbohm ovdje propituje kako su migracija kapverdskih žena i njihova organizacija brige o obitelji prihvaćene na Otoku, ali i u dijaspori.

Na kraju su dva prikaza tematskoga kompleksa migracija, mobilnost i rod koja kroz filmske priče i jezik filma prenose migrantska iskustva u zemlji primitka te iskustva onih koji su ostali kod kuće.

O filmu marokansko-belgijske redateljice Yasmine Kassari L'enfant endormi (2004) piše Marion Mangelsdorf u prilogu »Von einem schlummernden Fötus und verloschenen Lebenstraumen«. Dok muški članovi obitelji odlaze u Španjolsku za poslom, u jednome malome marokanskom selu zajedno ostaju četiri generacije žena. U središtu priče životi su dviju mladih žena, od kojih jedna ubrzo nakon muževa odlaska saznaje da je trudna. Njezina je svekrva nagovara da, prema starom običaju, »uspava « fetus i probudi ga ponovo kada se muž/otac vrati kući. Druga žena, koja već podiže sama svoju djecu, usprotivljuje se običaju. Film upozorava na ovisnosti i unutarnje konflikte žena koje žive u transkulturnom prostoru između »zaštićene neslobode« istočnoga $\mathrm{i}$ »tužne slobode« zapadnoga pristupa životu. Autorica zaključno napominje da su obje protagonistice tijekom filma našle put do vlastitog izričaja, ali ta istina ništa bitno ne mijenja u njihovoj nesigurnoj egzistenciji.

Osobita upečatljivost filma leži u činjenici što je redateljica Kassari, kako ističe Mangelsdorf, uspjela postići ono oko čega se i danas u postkolonijalnoj i rodnokritičkoj teoriji uvijek iznova spori, a to je da se prešućenima i prešućenome "podari« govor. U filmu ti, inače nevidljivi i nečuti, sami govore, ne govori se o njima, preko njih, što je problem koji je osobito snažno senzibilizirala Gayatri Chakravorty Spivak u svojemu temeljnom tekstu »Can the Subaltern Speak? « Jer onaj kojeg se čuje i koji može govoriti u svoje ime, postaje subjekt; pozicija obično osporena siromašnima, ženama, "podčinjenima«. Stoga je govor "podčinjenih« (Subaltern) najčešće samo govor onih koji ih zastupaju, u opasnosti da više prikrije negoli (raz)otkrije. Film Yasmine Kassari postavlja na kraju tužno ali važno pitanje: koje to privilegije mogu, i mogu li uopće, uživati oni koji su (konačno) stekli poziciju subjekta, koju cijenu moraju za njih platiti?

U filmu Fremde Haut redateljice Angeline Maccarone (2005) riječ je, naprotiv, o iskustvima strankinje (Fariba) koja zbog svoje homoseksualnosti bježi iz Irana u Njemačku i preuzima lik, »kožu « umrlog sunarodnjaka (Siamak) kako bi izbjegla deportaciju. Film analizira Elke Gramespacher u pri- 
logu »Dass Fremde als radikale Erfahrung - Fremde Haut (2005) von Angelina Maccarone und Judith Kaufmann « prateći dinamičnu igru »skrivača « između vlastitosti i stranosti, u etničkome i rodnom smislu. Siamak alias Fariba - i svi akteri koji s njom/s njim dolaze u kontakt - u toj su emocionalnoj priči u stalnom suočavanju, propitivanju stvarnoga i zamišljenoga, u (re) konstruiranju te, $u$ odnosu na stranost vanjskog tijela kao i onoga unutarnjeg, u neprekidnom gibanju.

Europa postaje »utvrda « koja se brani od useljavanja migranata iz izvaneuropskih prostora, stigmatizirajući ih kao »prodor stranaca «, »sukob civilizacija«, opasnost od "paralelnih društava«. Migranti stoga često postaju simbol drugosti, u opreci s kojom se izgrađuju i jačaju nacionalni identiteti većine. Namjera je ove knjige, $u$ kojoj su obrađene teme konstruirane na temelju migrantskih iskustava, razotkriti stereotipne predodžbe o drugosti, iz perspektive drugog, te istraživače i zainteresirane čitatelje tako približiti migrantskoj problematici. 
